\title{
Localization and characterization of EGF/TGF- $\alpha$ receptors on peri-implantation trophoblast in sheep
}

\author{
N. Gharib-Hamrouche, N. Chêne, M. Guillomot and J. Martal \\ Institut National de la Recherche Agronomique, Unité d'Endocrinologie de l'Embryon, Station de \\ Physiologie animale, 78352 Jouy-en-Josas Cédex, France
}

\begin{abstract}
Receptors for epidermal growth factor (EGF) have been identified on the ovine trophoblast as early as day 15 of gestation. A radioligand assay with ${ }^{125}$ I-labelled EGF was used to detect high and low affinity binding sites on the trophoblastic and placental membranes. The binding of ${ }^{125}$ I-labelled EGF was inhibited by increasing concentrations of unlabelled EGF. Competition studies with other peptide hormones including transforming growth factor $\alpha$ (TGF- $\alpha$ ), insulin-like growth factor-I (IGF-I) and ovine placental lactogen confirmed the specificity of EGF/TGF- $\alpha$ for its receptor. Cross-linking experiments using disuccinimidyl suberate (DSS) revealed a radiolabelled band of relative molecular mass $170 \mathrm{kDa}$. Immunohistochemical localization of the receptors demonstrated their distribution on the epithelial layer cells. The presence of receptors for EGF/TGF- $\alpha$ suggests that these factors could be involved in the regulation of embryonic development and fetal growth.
\end{abstract}

\section{Introduction}

Epidermal growth factor (EGF) was first isolated from mouse submaxillary gland (Cohen, 1962) and subsequently from various other organs and body fluids of mammals. EGF stimulates the growth of cells in vivo (Cohen and Elliot, 1963; Cohen, 1965; Carpenter and Cohen, 1979; Gospodarowicz, 1981) and in vitro (Sun and Green, 1977; Gospodarowicz et al., 1978; Carpenter and Cohen, 1979; Adamson and Rees, 1981; Hata et al., 1990). Through its ability to act as a mitogen, EGF may play a role in fetal and placental growth (O'Keefe et al., 1974; Adamson et al., 1981; Thorburn et al., 1981). In fact, EGF stimulates the proliferation of embryonic cells both in monolayer cultures and during embryonic morphogenesis in vivo and in vitro (Sundell et al., 1975; Goldin and Opperman, 1980; Pratt, 1980; Yoneda and Pratt, 1981; Kaplowitz et al., 1982; Gross et al., 1986).

The physiological actions of EGF result from its binding to specific receptors present on the outer cell membranes of target cells. The EGF receptor is a glycoprotein with tyrosine kinase activity (Cohen and Carpenter, 1975; Schlessinger et al., 1983). This receptor has been detected in numerous tissues, including the uterus (Hofmann et al., 1984) and the placenta (Hock and Hollenberg, 1980; Carson et al., 1983; Lai et al., 1986). However, despite the wealth of literature on EGF and its receptor in placental function, we are not aware of any studies that describe the presence of the EGF receptor in the preimplantation ovine trophoblast, as the embryo prepares to adhere to the uterine epithelium. Moreover, at this time, the conceptus undergoes rapid growth and development. The factors that control cell proliferation and remodelling in the developing blastocyst are not well known, but EGF may be involved in these processes.

Received 10 July 1992.
Uterine tissues from several species contain various polypeptide mitogens, including EGF (Brigstock et al., 1989).

In the present study, we have investigated and characterized the binding sites for EGF on the ovine trophoblast at the implantation period. In comparison, we also used third-term ovine placentae, which express a high number of EGF/TGF- $\alpha$ receptors on the microvillus plasma membranes.

\section{Materials and Methods}

\section{Animals and tissues}

Oestrus was synchronized in Préalpes du Sud ewes with intravaginal sponges $(40 \mathrm{mg}, 17 \alpha$-acetoxy- $9 \alpha$-fluoro-11 $\beta$ hydroxyprogesterone; Intervet, France), which were removed after 14 days. Ewes then received one i.m. injection of 500 iu PMSG (Intervet, France). On the day of oestrus, which occurred $48 \mathrm{~h}$ later and was designated as day 0 , the ewes were mated twice. Ewes were killed on days 15, 30 and 120 of gestation. The reproductive tract was removed. Conceptuses (day 15) were collected by flushing the uterine horns with sterile $0.1 \mathrm{~mol}$ $\mathrm{PBS} \mathrm{I}^{-1}, \mathrm{pH} 7.2$, or recovered by incision of the uterus (days 30 and 120). The trophoblast was separated from the embryo, yolk sac and allantoic membranes. From day 120, only fetal cotyledons were used for experiments.

Tissues were used either fresh or frozen in liquid nitrogen and stored at $-70^{\circ} \mathrm{C}$ until required.

\section{Growth factors and peptides}

Mouse epidermal growth factor (Receptor grade) from Genzyme Corporation, UK; transforming growth factor- $\alpha$, human recombinant from Promega Corporation, USA; insulin-like 
growth factor-I, recombinant analogue of human somatomedin C from Amersham International plc, UK were used in this study. The ovine placental lactogen was purified in our laboratory (Martal, 1978). Mouse EGF was iodinated, using the method of Greenwood et al. (1963). In these conditions, the specific activity of ${ }^{125}$ I-labelled EGF obtained was from 70 to $200 \mu \mathrm{Ci} \mu \mathrm{g}^{-1}$.

\section{Membrane preparation}

Membranes were prepared from ovine extraembryonic tissues (trophoblast, fetal cotyledons) using the procedure of Shiu et al. (1973) as modified by Martal and Djiane (1977). The following steps were carried out at $4^{\circ} \mathrm{C}$. The tissue was cut into small pieces and homogenized with an ultra-turrax homogenizer, in $0.3 \mathrm{~mol}$ sucrose $\mathrm{l}^{-1}$. The homogenate was filtered through two layers of cheese-cloth and centrifuged at $15000 \mathrm{~g}$ for $20 \mathrm{~min}$ to isolate intracellular organelles. The supernatant was then ultracentrifuged at $105000 \mathrm{~g}$ for $90 \mathrm{~min}$. The pellet was washed twice and resuspended, using a glass homogenizer, in $25 \mathrm{mmol}$ Tris- $\mathrm{HCl}$ buffer $\mathrm{I}^{-1}$ ( $\mathrm{pH} 7.5$ ), $10 \mathrm{mmol} \mathrm{MgCl}_{2} \mathrm{l}^{-1}$. The protein concentration was determined by the method of Lowry et al. (1951), using BSA as a standard. Preliminary studies indicated that membrane preparations could be stored for more than six months at $-20^{\circ} \mathrm{C}$ without change in its ability to bind EGF.

\section{Radioligand assay}

The assay was performed on membranes from the three different stages of pregnancy. To each assay tube was added successively $200 \mu \mathrm{l}$ of assay buffer $\left(25 \mathrm{mmol}\right.$ Tris- $\mathrm{HCl} \mathrm{l}^{-1}$ $\mathrm{pH} 7.5,10 \mathrm{mmol} \mathrm{MgCl}_{2} 1^{-1} 0.1 \%$ (w/v) BSA: RIA gradeSigma, France), $100 \mu \mathrm{l}$ of mouse EGF (1-200 $\mathrm{ng} \mathrm{m}^{-1}$ ), $100 \mu \mathrm{l}$ of ${ }^{125}$ I-labelled mouse EGF (100 000 c.p.m.) and ovine membranes (100 $\mu \mathrm{l}$ containing $250 \mu \mathrm{g}$ of proteins). The binding reaction was performed at room temperature for $3 \mathrm{~h}$ and was stopped by the addition of $1.5 \mathrm{ml}$ assay buffer to each tube. The membranes were collected by centrifugation at $2500 \mathrm{~g}$ for $30 \mathrm{~min}$, at $4^{\circ} \mathrm{C}$. The supernatant was discarded and the amount of radioactivity in the pellet measured on an LKB gamma counter. In some experiments, membrane preparations were incubated for various periods. The effect of increasing concentrations of membrane proteins on the binding efficiency was also examined.

The results were expressed as specific binding: difference between total and nonspecific binding, which was carried out in the presence of 1000-fold excess concentration of unlabelled EGF.

\section{Saturation analysis}

Saturation analysis was performed over a range of 0.04$3.20 \mathrm{nmol}{ }^{125} \mathrm{I}$-labelled EGF $1^{-1}$. Nonspecific binding at each concentration of radiolabelled EGF was determined in the presence of unlabelled EGF at 1000-fold excess concentration.

\section{Competition studies}

Specificity of EGF binding was checked in the presence of the following competitors: TGF- $\alpha$, IGF-I and ovine placental lactogen. The radioligand exchange assay was done, but with the substitution of the various peptides for unlabelled EGF.

\section{Determination of molecular mass of EGF-binding sites}

The membranes were incubated with ${ }^{125}$ I-labelled EGF, in the absence or presence of unlabelled EGF, at $\mathrm{pH} 7.5$, for $3 \mathrm{~h}$ at room temperature. At the end of incubation, $1.5 \mathrm{ml}$ ice-cold binding buffer was added and the membranes centrifuged as described in the radioreceptor assay. The pellet was then washed twice with ice-cold PBS buffer, and subjected to crosslinking in the presence of $0.3 \mathrm{mmol}$ disuccinimidyl suberate $\mathrm{I}^{-1}$ for $15 \mathrm{~min}$ at room temperature. The cross-linking agent was dissolved in dimethyl sulfoxide, immediately before use, and added to the membrane suspension to give a final concentration of $3 \%$ dimethyl sulfoxide in the binding buffer. The reaction was terminated by rapid centrifugation and washing of the membranes at $4^{\circ} \mathrm{C}$, with excess binding buffer. The membrane pellets were solubilized in $100 \mu \mathrm{l}$ of electrophoresis sample buffer containing $50 \mathrm{mmol}$ Tris- $\mathrm{HCll}^{-1} \mathrm{pH} 6.8,4 \%(\mathrm{w} / \mathrm{v})$ sodium dodecyl sulfate (SDS), $6 \%(\mathrm{w} / \mathrm{v})$ sucrose and $2 \%(\mathrm{v} / \mathrm{v})$ bromophenol blue, in the presence of $50 \mathrm{mmol}$ dithiothreitol $1^{-1}$. Samples were immediately heated to $100^{\circ} \mathrm{C}$ for $5 \mathrm{~min}$, rapidly centrifuged $(2500 \mathrm{~g}$ for $10 \mathrm{~min}$ ) and analysed by onedimensional SDS PAGE using $7.5 \%$ acrylamide in the separating gel, according to the method of Laemmli (1970). After electrophoresis, the gels were stained, destained, dried and exposed to Hyperfilm $B_{\max }$ (Amersham International plc) for $2-3$ weeks at $-70^{\circ} \mathrm{C}$, with intensifying screens.

\section{Immunohistofluorescence}

Rabbit polyclonal antibody (Ab-4) against human EGF receptor (residues 1005-1016) was obtained from Oncogene Science Inc, USA. The tissues were fixed by immersion in $4 \%$ paraformaldehyde and embedded in paraffin. The sections $(5 \mu \mathrm{m})$ were deparaffinized in xylene and treated with $0.05 \%$ saponin for $30 \mathrm{~min}$ at room temperature. The sections were incubated with $10 \%$ goat serum in PBS for $1 \mathrm{~h}$ to block nonspecific binding of IgG. The antibody Ab-4 was used at a 1:10 dilution of the stock solution in PBS-2\% BSA. The incubation was carried out either for $2 \mathrm{~h}$ at room temperature or overnight at $4^{\circ} \mathrm{C}$. After three washes in PBS-2\% BSA (10 min each), the sections were incubated with 1:200 goat antirabbit IgG-FITC (Pasteur Institute, France). As negative control, sections were incubated in nonimmune rabbit serum. After mounting, the slides were stored in the dark at $4^{\circ} \mathrm{C}$ until observations using a fluorescence microscope.

\section{Statistical analysis}

Specific binding data was analysed by a ligand computer program (Munson and Robard, 1980) to yield the dissociation constant $\left(K_{\mathrm{d}}\right)$ and the number of specific binding sites.

One way analyses of variance followed by Student-NewmanKeuls tests were used for statistical comparison.

\section{Results}

The optimal assay conditions for ${ }^{125}$ I-labelled EGF binding to trophoblastic or placental membranes were first defined for 

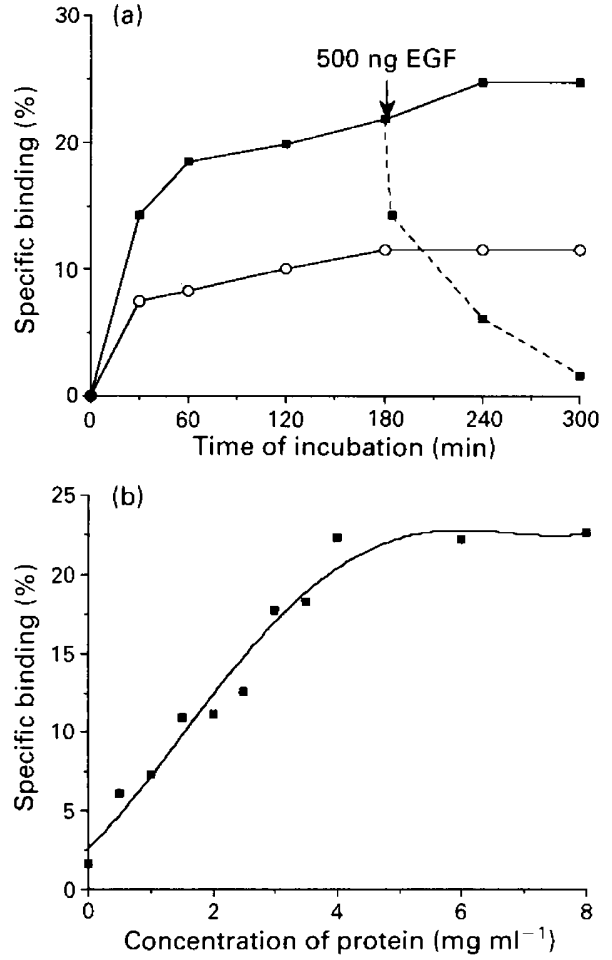

Fig. 1. (a) Time course of specific binding of ${ }^{125}$ I-labelled epidermal growth factor (EGF) to ovine 15-day-old trophoblast membranes, at $4^{\circ} \mathrm{C}(\mathrm{O})$ and $22^{\circ} \mathrm{C}(\boldsymbol{\square})$. Dissociation of ${ }^{125} \mathrm{I}$-labelled EGF (-- - ) from trophoblast membranes can be obtained by addition of unlabelled EGF $(500 \mathrm{ng})$ after equilibrium is reached. (b) Effect of increasing concentration of protein on the specific binding of ${ }^{125}$ I-labelled EGF to ovine trophoblastic membrane preparation from day 15 of pregnancy. Data are the means of duplicate incubations in a representative experiment.

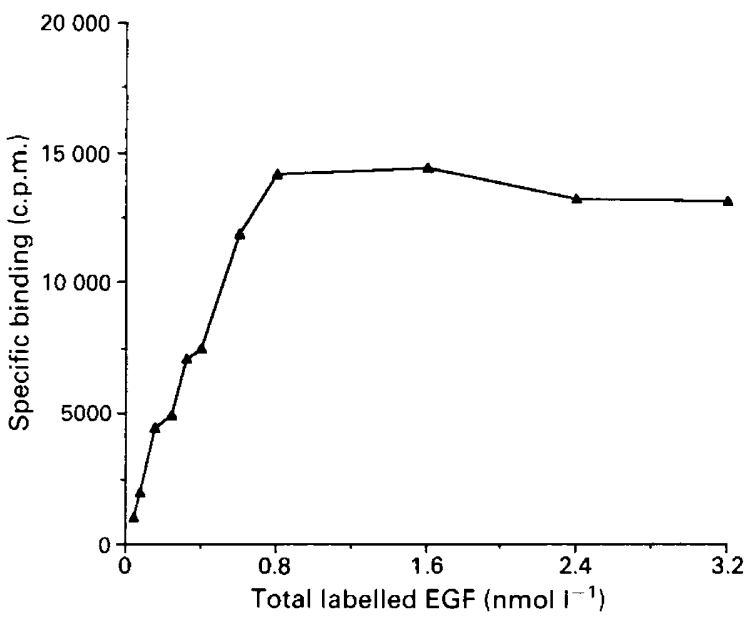

Fig. 2. Saturation curve of ${ }^{125}$ I-labelled epidermal growth factor specific binding to ovine trophoblast membranes of a typical experiment.

further characterization of binding sites. Although significant specific binding of ${ }^{125} \mathrm{I}$-labelled EGF to trophoblast membranes was obtained at $4^{\circ} \mathrm{C}$, maximal specific binding was attained at

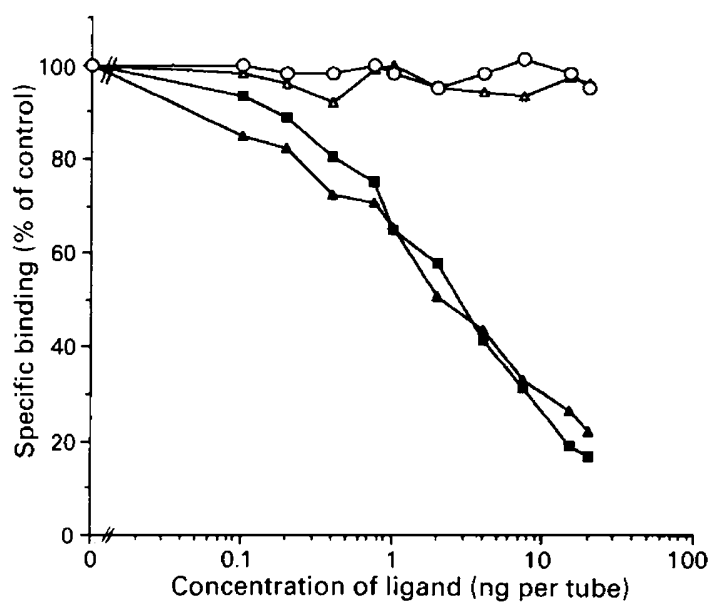

Fig. 3. Ligand specificity of the ovine trophoblast binding sites for epidermal growth factor (EGF). Each point is the mean of duplicate incubations in a representative experiment performed by addition of increasing concentrations of EGF $(\boldsymbol{\square}), \operatorname{TGF}-\alpha(\boldsymbol{\Delta}), \operatorname{IGF}-\mathrm{I}(\Delta)$ and ovine placental lactogen $(O)$ to trophoblastic membranes incubated with ${ }^{125}$ I-labelled EGF.
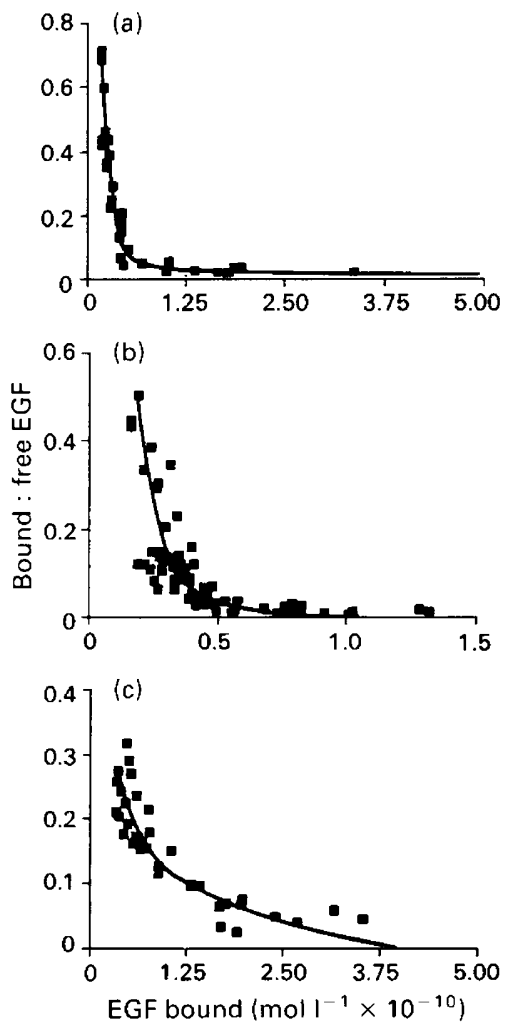

Fig. 4. Scatchard analysis of specific binding of the ${ }^{125} \mathrm{I}$-labelled epidermal growth factor (EGF) to ovine trophoblastic and placental membranes. ${ }^{125}$ I-labelled EGF $(0.08-0.24 \mathrm{pmol})$ was incubated with $250 \mu \mathrm{g}$ membrane protein for $3 \mathrm{~h}$ at $22^{\circ} \mathrm{C}$. Each curve corresponds to the pooled data at (a) 15, (b) 30, and (c) 120 days of gestation. 
Table 1. Ontogeny of the high- and low-affinity epidermal growth factor receptors during pregnancy in sheep

\begin{tabular}{|c|c|c|c|c|}
\hline \multirow{2}{*}{$\begin{array}{l}\text { Days of } \\
\text { pregnancy }\end{array}$} & \multicolumn{2}{|c|}{ High-affinity receptors } & \multicolumn{2}{|c|}{ Low-affinity receptors } \\
\hline & $K_{d}\left(10^{-11} \mathrm{~mol} \mathrm{l}^{-1}\right)$ & fmol $\mathrm{mg}^{-1}$ tissue & $K_{\mathrm{d}}\left(10^{-8} \mathrm{~mol} \mathrm{l}^{-1}\right)$ & fmol $\mathrm{mg}^{-1}$ tissue \\
\hline $15(n=6)$ & $4.11 \pm 1.16$ & $76.4 \pm 2.3$ & $3.54 \pm 0.43$ & $2364 \pm 267^{* *}$ \\
\hline $30(n=6)$ & $4.97 \pm 0.28$ & $75.0 \pm 1.6$ & $0.59 \pm 0.13$ & $326 \pm 92^{*}$ \\
\hline $120(n=4)$ & $7.30 \pm 3.56$ & $71.3 \pm 7.2$ & $0.38 \pm 0.15$ & $756 \pm 250^{*}$ \\
\hline
\end{tabular}

The values represent means \pm SEM.

${ }^{* *}$ Significantly different from other groups $(P<0.01)$.

${ }^{*}$ Significantly different between the two values $(P<0.05)$.
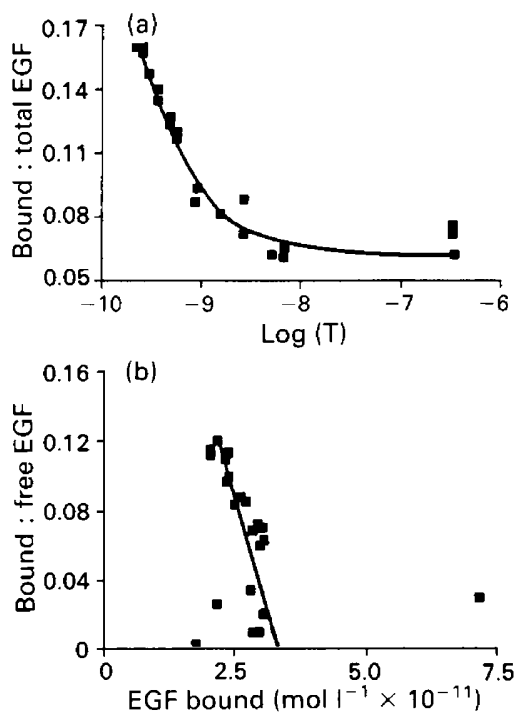

Fig. 5. (a) Displacement curve and (b) Scatchard plot of specific binding of ${ }^{125}$ I-labelled epidermal growth factor to day 15 trophoblast membranes which present only one class of binding sites, in three experiments. T: total radioactivity.

$22^{\circ} \mathrm{C}$, after $3 \mathrm{~h}$ of incubation (Fig. Ia). In addition, over $80 \%$ of this binding was reached from the first hour. Thus, binding was clearly dependent on time and temperature. ${ }^{125}$ I-labelled EGF binding to membranes was reversible. The addition of unlabelled ligand $\left(100 \mu \mathrm{l}, 5 \mu \mathrm{g} \mathrm{ml}^{-1}\right)$ at the end of incubation immediately displaced the specific binding from 19.2 to $14.2 \%$. This value decreased to $1.6 \%$ in $2 \mathrm{~h}$. The optimal membrane protein concentration for maximal specific binding was determined by incubating with various amounts of protein. The specific binding of ${ }^{125}$ I-labelled EGF increased in a linear fashion as a function of protein concentration up to $4 \mathrm{mg} \mathrm{ml}^{-1}$, and there was no further significant increase in EGF binding at higher protein concentrations (Fig. $\mathrm{Ib}$ ). On the basis of these data, all subsequent binding experiments were performed at $22^{\circ}-25^{\circ} \mathrm{C}$ for $3 \mathrm{~h}$, but with regard to the small amount of trophoblastic tissue at day 15 of pregnancy, a protein concentration of $2.5 \mathrm{mg} \mathrm{m}^{-1}$ was chosen for the routine binding assay.

Incubation of the membrane fractions with increasing concentration of ${ }^{125}$ I-labelled EGF produced a saturation of the binding protein at $0.8 \mathrm{nmol}^{-1}$ (Fig. 2). The binding of ${ }^{125} \mathrm{I}$ labelled EGF was displaced by unlabelled EGF and TGF- $\alpha$ in a dose-dependent manner (Fig. 3), but not by any other growth factor or hormone used (IGF-I, ovine placental lactogen), at a 1000 -fold excess of the concentration of labelled EGF. More than $90 \%$ of ${ }^{125}$ I-labelled EGF bound to membranes could be displaced by the highest concentration $\left(10 \mu \mathrm{g} \mathrm{ml}^{-1}\right)$ of EGF or TGF- $\alpha$ indicating that nonspecific binding, which does not change with the age of tissue, contributed to less than $10 \%$ of the total binding of EGF to trophoblast membranes.

At the three gestational ages studied, Scatchard analysis resulted in curvilinear plots indicating the presence of two classes of receptor (Fig. 4), with estimated dissociation constants of approximately $10^{-11}$ and $10^{-8} \mathrm{~mol}^{-1}$ for the high- and low-affinity receptors, respectively. The ontogeny of EGF binding sites present on the trophoblast is given (Table 1). Affinity of EGF to its receptor was similar at various gestational ages studied. The majority of the ${ }^{125}$ I-labelled EGF binding was to the lower-affinity receptor class in which variations according to stage of pregnancy could be observed. The number of lowaffinity receptors was very important in early pregnancy, decreased to a low value after implantation and a small increase could be observed at late gestation. In contrast, there was no change in the number of high-affinity receptors. Nevertheless, at day 15 of gestation, $33 \%$ of the cases examined $(n=9)$ showed only high-affinity receptors (Fig. 5).

The autoradiograms of SDS-PAGE revealed a single band, corresponding to EGF-receptor with a relative molecular mass of $170 \mathrm{kDa}$ (Fig. 6). Specificity of binding was evident since it was displaced progressively by increasing doses of unlabelled EGF. Similar results were obtained with TGF- $\alpha$ (data not shown).

The immunohistochemical studies showed positive staining on the trophectoderm cells (Fig. 7a). A typical control obtained by using normal rabbit serum shows only background fluorescence (Fig. 7b).

\section{Discussion}

Most of the experiments investigating the role of EGF in mammalian embryogenesis have been developed in humans and rodents, especially mice. With few exceptions, pig (Corps et al., 


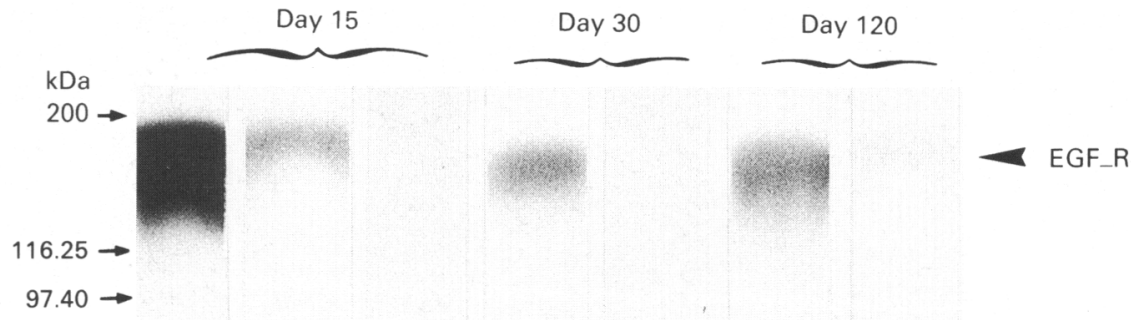

$66.20 \rightarrow$

$45.00 \rightarrow$

cold EGF

$$
(+)
$$

Fig. 6. Autoradiographic profile of ${ }^{125}$-labelled epidermal growth factor (EGF) binding to specific ovine trophoblastic and placental receptors in absence or presence of $500 \mathrm{ng}(+)$ and $1 \mu \mathrm{g}+$ of unlabelled EGF at days 15, 30 and 120 of gestation. High molecular weight markers used were: myosin, $\beta$ galactosidase, phosphorylase $b, B S A$ and ovalbumin.

1990) and cows (Watson et al., 1992), there is no more information on farm animals. In this study, EGF receptors were shown to be present on ovine trophoblast as early as day 15 of pregnancy, which corresponds to the beginning of implantation in this species. Similar results have been obtained in pigs in which ${ }^{125}$ I-labelled EGF bound to trophoderm cells from 15- to 19-day-old blastocysts (Corps et al., 1990).

Because both EGF and TGF- $\alpha$ bound with the same affinity to EGF receptors, these EGF binding sites on ovine trophoblast may represent receptors for EGF or TGF- $\alpha$. The rapid rate of association of labelled ligand with the receptor site agrees with the data of $O^{\prime}$ Keefe et al. (1974) and Carpenter et al. (1975). The binding is specific, saturable and reversible. Incomplete dissociation following addition of excess unlabelled EGF may be due to the formation of non-dissociable covalent binding of ${ }^{125}$ I-labelled EGF to some receptor sites. The formation of this covalent binding may have resulted from the use of chloramine $\mathrm{T}$ in the radioiodination procedure (Comens et al., 1982; Wynn et al., 1989). In the study reported here, EGF receptor concentration varies with gestational age and the highest concentration appears in early pregnancy (Chegini and Rao, 1985; Marou et al., 1987). The preimplantation period in sheep is a time of extensive cellular remodelling during which the day-11 spherical blastocyst of $1 \mathrm{~mm}$ diameter extends to a filamentous thread up to $10 \mathrm{~cm}$ in length in 3-4 days. Damjanov et al. (1984) showed that proliferative epithelial cells have a relatively large number of EGF receptors, but after cell differentiation and arrest of proliferation, the number of EGF receptors is reduced to low values. This finding suggests that the factor might play a role in regulating trophoblast growth and embryo development.
Scatchard analysis discloses the possibility of two classes of receptor: a major class of low-affinity and a minor class of highaffinity EGF receptors. High- and low-affinity sites have been described previously in the human placenta (O'Keefe et al., 1974; Carson et al., 1983) and in mouse placenta (Smith and Talamantes, 1986). However, only one type of receptor was described in mouse embryonic tissues, including placenta by Adamson and Meek (1984). The functional implications of the existence of high-affinity and low-affinity EGF receptors are largely obscure. The high-affinity EGF receptors have been implicated as the subclass through which EGF predominantly exerts its mitogenic effect. A correlation between the relative number of high-affinity EGF receptors and the activation of EGF receptor kinase has been established (Defize et al., 1989). However, it seems that a negative cooperativity was exerted by this growth factor. In a great variety of cells, EGF reduced the affinity of its own receptors, which undergo a ligand-dependent transition from a homogeneous (high-affinity) population to a heterogeneous population and finally to a homogeneous (low-affinity) population (Wiley et al., 1989). Cross-linking studies showed a molecular mass of $170 \mathrm{kDa}$ in agreement with previous characterization by Carpenter (1987). The intensity of autoradiographic bands is greatest at day 15 of pregnancy, indicating a very large number of receptors at this stage. Immunohistological observations confirmed the presence of EGF receptors in ovine trophoblastic tissue, with a localization on ectodermal cells.

We attempted to measure EGF in sheep using the human EGF radioimmunoassay and two radioreceptor assays using a suspension of membranes of human A431 cells and sheep 

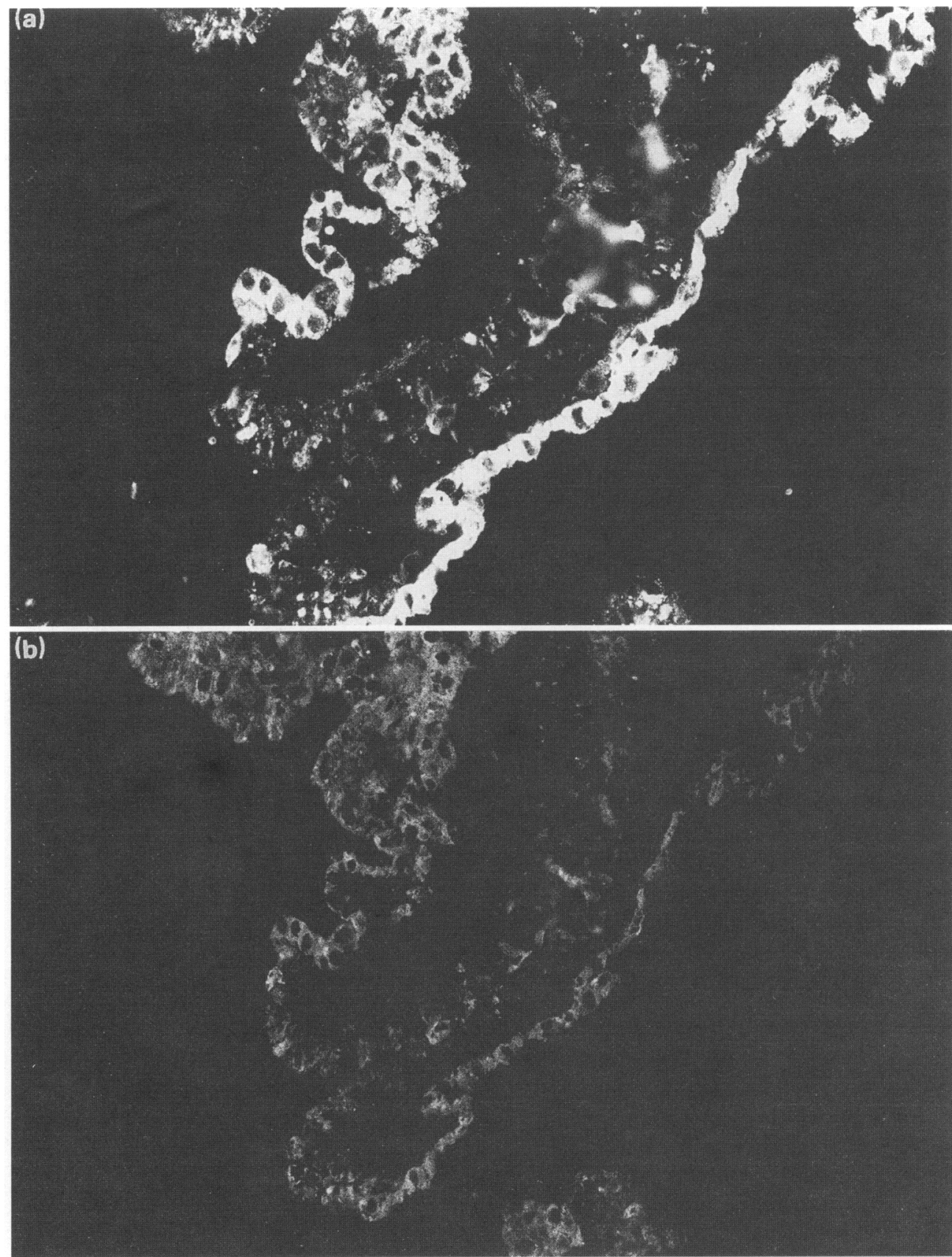

Fig. 7. Immunohistochemical staining of the day 15 ovine trophoblast using the anti-human epidermal growth factor receptor rabbit antibody (Ab-4). (a) Intense immunoreactivity of EGF receptors on the trophectoderm cells $(\times 400)$; (b) Negative control serum $(\times 320)$.

placental membranes. With these quantitative methods, we could not detect significant amounts of EGF in culture media or extracts of ovine conceptus from days 12 to 30 of gestation. EGF was not detected in allantoic or amniotic fluids, although EGF could be detected by radioreceptor assay in saliva, urine and milk (Gharib-Hamrouche, unpublished data). Our inability to detect any ovine embryonic EGF or EGF-like activity may be due to the inherent limitations of the assay methods that were used. The radioimmunoassay could measure concentrations in the $\mathrm{pg} \mathrm{ml}^{-1}$ range, but is hampered by high specificity. For example, despite the high degree of sequence similarity between human and mouse EGF, antisera to human EGF do not crossreact with mouse EGF. A similar lack of immunological crossreactivity with the ovine EGF has been reported by Thorburn et al. (1981) and may explain the inability to detect any ovine EGF using antisera to human EGF. Radioreceptor assays display less species specificity than radioimmunoassays, but the levels of ovine EGF activity, like other growth factors mediating cell-cell interactions, are below the limit of sensitivity of the assay $\left(0.1 \mathrm{ng} \mathrm{ml}^{-1}\right)$. The nature and source of the 
physiologically relevant ligand therefore remains to be established. In late pregnancy of humans, Eaton et al. (1987) found that only very small amounts of intact ${ }^{125}$ I-labelled EGF $(0.2 \%$ of that added to maternal side) were transported from the maternal to the fetal circulation. However, the possibility that EGF is provided from the plasma of the mother cannot be completely discounted. The uterine luminal fluid has been shown to contain molecules with growth promoting activity for cells in culture: IGF-I, heparin-binding growth factors and a novel factor that has been termed uterine luminal fluid mitogen (Simmen et al., 1989). Most of the polypeptides found in the luminal uterine fluid derived from the plasma by transudation (Roberts and Parker, 1974; Roberts et al., 1976). A further possibility has been proposed by Nexo et al. (1980) and Popliker et al. (1987). With regard to the presence of EGF receptor mRNA in fetal mouse but low amounts or absence of EGF and EGF precursor mRNA in most fetal rodent tissues, it is possible that the ligand for embryonic or fetal receptors in mice is TGF- $\alpha$ rather than EGF. In fact, it is well known that EGF and TGF- $\alpha$ bind to the same cell surface receptors and compete with each other for binding sites. These two growth factors have similar actions, but there are distinguishable differences in their biological activity. Rappolee et al. (1988) and Werb (1990) detected TGF- $\alpha$ mRNA sequences and peptides in preimplantation mouse development. However, Han et al. (1987) showed that TGF- $\alpha$ mRNA is expressed in the decidual cells, which also present EGF/TGF- $\alpha$ binding sites. Similar data have been obtained for the sheep fetus by Freemark and Comer (1978).

Thus, TGF- $\alpha$ via its receptor, may have an autocrine or paracrine function or both functions on decidual growth and could probably take part in the process of implantation and in the trophoblast elongation or embryo development.

We would like to thank M. C. Lacroix for her help with the ligandcomputer program and A. Solari for statistical analysis.

\section{References}

Adamson ED and Meek J (1984) The ontogeny of epidermal growth factor receptors during mouse development Developmental Biology $10362 m 70$

Adamson ED and Rees AR (1981) Epidermal growth factor receptors Molecular and Cellular Biochemistry 34 129-152

Adamson ED, Deller MJ and Warshaw JB (1981) Functional EGF receptors are present in mouse embryos Nature $291656-659$

Brigstock DR, Heap RB and Brown KD (1989) Polypeptide growth factors in uterine tissues and secretions Joumal of Reproduction and Fertility 85 747-758

Carpenter G (1987) Receptors for epidermal growth factor and other polypeptide mitogens Annual Review of Biochemistry 56 881-914

Carpenter G and Cohen S (1979) Epidermal growth factor Annual Review of Biochemistry 48 193-216

Carpenter G, Lembach KJ, Morrison MM and Cohen S (1975) Characterization of the binding of ${ }^{125}$ I-labelled epidermal growth factor to human fibroblasts Journal of Biological Chemistry 250 4297-4304

Carson SA, Chase R, Ulep E, Scommegna A and Benveniste R (1983) Ontogenesis and characteristics of epidermal growth factor receptors in human placenta American Joumal of Obstetrics and Gynecology 147 932-939

Chegini N and Rao CV (1985) Epidermal growth factor binding to human amnion, chorion, decidua, and placenta from mid- and term pregnancy: quantitative light microscopic autoradiographic studies Journal of Clinical Endocrinology and Metabolism 61 529-535

Cohen S (1962) Isolation of a mouse submaxillary gland protein accelerating incisor eruption and eye lid opening in the newborn animal Journal of Biological Chemistry 237 1555-1562
Cohen S (1965) The stimulation of epidermal proliferation by a specific protein (EGF) Developmental Biology 12 394-407

Cohen S and Carpenter G (1975) Human epidermal growth factor: isolation and chemical and biological properties Proceedings of the National Academy of Sciences, USA 72 1317-1321

Cohen S and Elliot GA (1963) The stimulation of epidermal keratinisation by a protein isolated from the submaxillary gland of the mouse Joumal of Investigative Dermatology 40 i-5

Comens PG, Simmer RL and Baker JB (1982) Direct linkage of ${ }^{125}$ I-epidermal growth factor to cell surface receptors. A useful artifact of chloramine $T$ treatment Journal of Biological Chemistry 257 42-45

Corps AN, Brigstock DR, Littlewood CJ and Brown KD (1990) Receptors for epidermal growth factor and insulin-like growth factor-I on preimplantation trophoderm of the pig Development 110 221-227

Damjanov I, Mildner B and Knowle BB (1984) Immuno-histochemical localization of the epidermal growth factor in normal human tissues Laboratory Investigation 55 588-592

Defize LHK, Boonstra J, Meisenhelder J, Kruijer W, Tertoleer LGJ, Tilly BC, Hunter T, Van Bergen en Henegouwen PMP, Moolenaar WH and de Laat SW (1989) Signal transduction by epidermal growth factor occurs through the subclass of high affinity receptors Joumal of Cell Biology 109 2495-2507

Eaton BM, Richards RC and Contractor SF (1987) Uptake and metabolism of epidermal growth factor in the perfused human placenta Journal of Developmental Physiology 9 69-78

Freemark M and Comer M (1987) Epidermal growth factor (EGF)-like transforming growth factor (TGF) activity and EGF receptors in ovine fetal tissues: possible role for TGF in ovine fetal development Pediatric Research 22 609-615

Goldin GV and Opperman LA (1980) Induction of supernumerary tracheal buds and the stimulation of DNA synthesis in the embryonic chick lung and trachea by epidermal growth factor Journal of Embryology and Experimental Morphology 60 235-243

Gospodarowicz D (1981) Epidermal and nerve growth factors in mammalian development Annual Review of Physiology 43 251-263

Gospodarowicz D, Greenburg G, Bialecki H and Zetter BR (1978) Factors involved in the modulation of cell proliferation in vivo and in vitro: the role of fibroblast and epidermal growth factors in the proliferative response of mammalian cells In Vitro 14 85-118

Greenwood FC, Hunter WM and Glover JS (1963) The preparation of ${ }^{13} \mathrm{I}$ labelled human growth hormone of high specific activity Biochemical Journal 89 114-123

Gross I, Dynia DW, Rooney SA, Smart DA, Warshaw JB, Sissom JF and Hoath SB (1986) Influence of epidermal growth factor on fetal rat lung development in vitro Pediatric Research 20 473-477

Han VK, Hunter ES, IIl, Pratt RM, Zendegui JG and Lee DC (1987) Expression of rat transforming growth factor $\alpha$ mRNA during development occurs predominantly in the maternal decidua Molecular and Cellular Biology 7 2335-2.343

Hata R, Bessen C, Bringas P, Jr, Hsu MY and Slavkin HC (1990) Epidermal growth factor regulates gene expression of both epithelial and mesenchymal cells in mouse molar tooth organs in culture Biology International Reports 14 509-519

Hock RA and Hollenberg MD (1980) Characterization of receptor for epidermal growth factor-Urogastrone in human placenta membranes Joumal of Biological Chemistry 255 10731-10736

Hofmann GE, Rao CV, Barrows GH, Schultz GS and Sanfilippo JS (1984) Binding sites for epidermal growth factor in human uterine tissues of leiomyomas Joumal of Clinical Endocrinology and Metabolism 58 880-884

Kaplowitz PB, D'Ercole AJ and Underwood LE (1982) Stimulation of embryonic mouse limb bud mesenchymal cell growth by peptide growth factors Journal of Cellular Physiology 112 353-359

Laemmli UK (1970) Cleavage of structural proteins during the assembly of the head of bacteriophage T4 Nature 227 680-685

Lai WH, Guyda HJ and Bergeron JJM (1986) Binding and internalization of epidermal growth factor in human term placental cells in culture Endocrinology 118 413-423

Lowry OH, Rosenbrough NJ, Farr AL and Randall RJ (1951) Protein measurement with the folin phenol reagent Joumal of Biological Chemistry 193 265-275

Marou T, Matsuo H, Oishi T, Hayashi M, Nishino R and Mochizuki M (1987) Induction of differentiated trophoblast function by epidermal growth factor: relation of immunohistochemically detected cellular growth factor levels Journal of Clinical Endocrinology and Metabolism 64 744-750 
Martal J (1978) Placental growth hormone in sheep: purification, properties and variations Annales de Biologie Animale, Biochimie, Biophysique 18 45-51

Martal J and Djiane J (1977) The production of chorionic somatomammotrophin in sheep Joumal of Reproduction and Fertility 49 285-289

Munson PJ and Robard D (1980) Ligand: a versatile computerized approach to characterization of ligand-binding systems Analytical Biochemistry 107 220-239

Nexo E, Hollenberg MD and Cuatrecasas P (1980) Detection of epidermal growth factor-urogastrone and its receptor during fetal mouse development Proceeding of National Academy of Sciences, USA 77 2782-2785

O'Keefe E, Hollenberg MD and Cuatrecases $P$ (1974) Epidermal growth factor: characteristics of specific binding in membranes from liver, placenta and other target tissues Archives of Biochemistry and Biophysics 164 518-526

Popliker M, Shatz A, Avivi A, Ullrich A, Schlessinger J and Webb CG (1987) Onset of endogenous synthesis of epidermal growth factor in neonatal mice Developmental Biology 119 38-44

Pratt RM (1980) Involvement of hormones and growth factors in the development of the secondary palate. In Development in Mammals Vol. 4 pp 203-231 Ed. MH Johnson. Elsevier-North Holland, New York

Rappolee DA, Brenner CA, Schultz R, Mark D and Werb Z (1988) Developmental expression of PDGF, TGF-alpha, and TGF-beta genes in preimplantation mouse embryos Science 241 1823-1825

Roberts GP and Parker JM (1974) Macromolecular components of the luminal fluid from the bovine uterus journal of Reproduction and Fertility $\mathbf{4 0}$ 291-303

Roberts GP, Parker JM and Symonds HW (1976) Macromolecular components of genital tract fluid from the sheep Journal of Reproduction and Fertility $\mathbf{4 8}$ 99-107

Schlessinger J, Schreiber AB, Levi A, Lax I, Liberman T and Yarden Y (1983) Regulation of cell proliferation by epidermal growth factor Critical Review of Biochemistry 14 93-111
Shiu RPC, Kelly PA and Friesen HG (1973) Radioreceptor assay for prolactin and other lactogenic hormones Science $180968-970$

Simmen FA, Simmen RC and Bazer FW (1989) Maternal growth factors as mediators of embryonic and neonatal growth Biochemical Society Transaction $17587-589$

Smith WC and Talamantes F (1986) Characterization of the mouse placental epidermal growth factor: changes in receptor number with day of gestation Placenta 7 511-522

Sun TT and Green H (1977) Cultured epithelial cells of comea, conjunctiva and skin: absence of marked intrinsic divergence of other differentiated states Nature 269 489-492

Sundell H, Serenius F, Barthe T, Friedman C, Kanarek K, Escobedo M, Orth DM and Stahlman MT (1975) Effect of epidermal growth factor on fetal lamb lung maturation Pediatric Research 9 371-376

Thorburn GD, Waters MJ, Young IR, Dolling M, Buntine D and Hopkins PS (1981) Epidermal growth factor: a critical factor in fetal maturation? In The Fetus and Independant life (Ciba Foundation Symposium 86) pp 172-198 Pitman Press, London

Watson AJ, Hogan A, Hahnel A, Wiemer KE and Schultz GA (1992) Expression of growth factor ligand and receptor genes in the preimplantation bovine embryo Molecular Reproduction and Development 31 87-95

Werb Z (1990) Expression of EGF and TGF- $\alpha$ genes in early mammalian development Molecular Reproduction and Development 27 10-15

Wiley HS, Walsh BJ and Lund KA (1989) Global modulation of the epidermal growth factor receptor is triggered by occupancy of only a few receptors Joumal of Biological Chemistry 264 18912-18920

Wynn PC, Maddocks IG, Moore GPM, Panaretto BA, Djura P, Ward WG, Fleck E and Chapman RE (1989) Characterization and localisation of receptors for epidermal growth factor in ovine skin Journal of Endocrinology 121 8I-90

Yoneda T and Pratt RM (1981) Mesenchymal cells from the human embryonic palate are highly responsive to epidermal growth factor Science 213 563-565 